\title{
Sewage Water Effects on Okra (Abelmoschus esculentus (L) Moench) Growth Affected by Organic Matter, and Avm of Pseudomonas fluorescens
}

\author{
Abdul Khalil Gardezi*1, Sergio Roberto Marquez Berber ${ }^{2}$, Guillermo Carrillo Castañeda ${ }^{1}$, Hector Flores- \\ Magdaleno ${ }^{1}$, Gabriel Haro Aguilar ${ }^{1}$, Eduardo Valdes Velarde ${ }^{2}$, Miguel Jorge Escalona Maurice ${ }^{1}$ and Mario \\ Ulises Larque-Saavedra ${ }^{3}$
}

${ }^{1}$ Postgraduate College, Mexico

${ }^{2}$ Chapingo Autonomous University, Mexico

${ }^{3}$ Metropolitan Autonomous University, Mexico

*Corresponding author: Abdul Khalil Gardezi, Postgraduate College, Mexico.

Received Date: February 20, 2019

Published Date: March 26, 2019

\begin{abstract}
Okra (Abelmoschus esculentus) is a tropical crop, member of the Malvaceae family. Its fruits are grown and widely used in many countries of Asia and Africa. India is the main producer. It is cultivated in Mexico in small plots with scarce know-how. A sustainable and low-cost technology is needed to increase the profits of the farmers. Pseudomonas fluorescens have been used to increase germination and for biological control of pathogenic fungus. The study was done under greenhouse conditions. Two soils were used. One came from a parcel irrigated with sewage water and the other one was irrigated with clean water from a well. Half of the treatments were inoculated with Pseudomonas fluorescens. Four doses of vermicompost were applied as a source of organic matter. There were significant differences $(\mathrm{p} \leq 0.05)$ in most variables recorded due to the treatments. The soil irrigated with contaminated water only affected root length and fruit number. The plants inoculated with Pseudomonas fluorescens had better shoot and root growth, and fruit number, but it had no effect on fruit weight $(\mathrm{p} \leq 0.05)$. Vermicompost, as source of organic matter, also had a positive effect on Okra growth. Fruit number, and their dry weight augmented with the application of the lowest quantity of organic matter used ( $\left.25 \mathrm{t} \mathrm{ha}^{-1}\right)$. Irrigation with sewage water, inoculation with Pseudomonas fluorescens, and lower quantities of vermicompost can be used to increase the yields of Okra. The use of Pseudomonas fluorescens can help to overcome the negative effects of contaminated waters, and other environmental and biological stresses. Recommendations are made to validate this result under field conditions.
\end{abstract}

Keywords: Contaminated soils; Bacteria; Vermicompost; Okra yield; Germination test

\section{Introduction}

Okra (Abelmoschus esculentus (L) Moench), member of the Malvaceae family, is grown in the tropics, and widely used, as vegetable, for its fruits in many countries of Asia and Africa. Nigeria has the largest harvested area (1.46 million ha in 2016), but India is the main producer (5.5 million tons in 2016; FAO, 2018).

It is cultivated in Mexico, also as vegetable, for export in small plots with scarce know-how. It is an important source of income for the farmers.

A sustainable and low-cost technology is needed to increase the profits of the farmers. Flourescent pseudomonads are the most common group of soil microbes found in combination with organic matter and associated with the suppression of root diseases [1-3]. They have also this beneficial effect in okra $[4,5]$.

Pseudomonas fluorescens is a symbiotic species in plants that allows them to obtain the nutritional elements essential for their growth. This species is known for its ability to reduce the incidence of diseases in the roots of plants, as well as the inhibition of a large number of phytopathogens $[6,7]$.

The use of organic matter is also a sustainable alternative to provide nutrients $[8,9]$. Water is a scarce resource. Contaminated 
water can be used to irrigate crops. The need to know what kind of crops for human consumption can be grown in contaminated soils, and the application of inoculation compensation for the natural lack of nutrients has led to a series of studies with this purpose.

The present work assessed the growth and yield of plants of okra (Abelmoschus esculentus (L) Moench), inoculated with Pseudomonas fluorescens, fertilized with organic matter, and cultivated in soils irrigated with clean and contaminated waters.

\section{Materials and Methods}

The study was done in agricultural fields, and under greenhouse conditions at the Postgraduate College, Montecillo Campus, State of Mexico, in the spring and summer of 2017.

Two soils, from Tocuila, Texcoco, Mexico, were used. One came from a one-hectare parcel irrigated with sewage water and the other one was from another one-hectare field irrigated with clean water from a well. Geographical Information Systems were used. Sixteen wells were located using GPS in a digital orthophoto from the Mexican Institute of Geography and Informatics from 1996 with a $2 \mathrm{~m}$ pixel, scale $1: 20,000$.

From the soil samples obtained, a 17 variables chemical analysis, and a 12 variables agronomic analysis were performed. An Excel spreadsheet with the chemical, and the agronomic variables was constructed. It was transformed to Dbase later. The coordinates were transferred to a point map in GIS ArcView v. 3.2 associated to the spreadsheet using the Trigulat Irregular Network (TIN) method. This allowed analyzing the movement of chemical elements such as potentially toxic heavy metals from the samples [10].

The treatments were: planting in soil irrigated with sewage water and the other one with clean water. Both soils were collected at three depths $0-5,5-10$, and $10-40 \mathrm{~cm}$ from plots of one hectare each.

The Clemson spineless 80 cultivar of okra (Abelmoschus esculentus (L) Moench). In order to select the bacterial complex, a trial was done with five strains from the Molecular Genetics Lab of the Postgraduate College. A B of King culture media was used. The
Avm of Pseudomonas fluorescens was selected due to better seed protection against fungal attack.

The seeds were inoculated with the Avm of Pseudomonas fluorescens grown in B of King culture media and planted in bags with three $\mathrm{kg}$ of the soils described above.

Vermicompost was applied as a source of organic matter Four doses were applied. In every bag of three $\mathrm{kg}, 0,28.86 \mathrm{~g}, 57.7 \mathrm{~g}$, and $86.46 \mathrm{~g}$ of vermicompost were mixed. They were equivalent to 0,25 , 50 , and $75 \mathrm{t} \mathrm{ha}^{-1}$ of organic matter.

The experiment lasted 170 days. The variables evaluated were: plant height ( $\mathrm{PH}, \mathrm{cm})$, stem diameter (SD, $\mathrm{mm}$ ), leaf area $\left(\mathrm{LA}, \mathrm{cm}^{2}\right)$, number of leaves (NL, number), shoot fresh weight (SFW, g), shoot dry weight (SDW, g), fruit number (FN, number), fruit length (FL, $\mathrm{cm}$ ), fruit fresh weight (FFW, g), fruit dry weight (FDW, g), root length $(\mathrm{RL}, \mathrm{cm})$, root volume $\left(\mathrm{RV} \mathrm{cm}^{3}\right)$.

For the number of leaves, all of them were counted since the beginning until the end of the experiment.

A factorial arrangement with 16 treatments $(4 \times 2 \times 2)$ was used with a completely randomized block design with three replications. An analysis of variance for all variables registered was done. A Tukey mean comparison test was conducted for all the significant variables.

\section{Results and Discussion}

The locations used for sampling had deep soils. There were differences between the soils used in this experiment. Table 1 shows the average values for the chemical analysis of the sixteen wells sampled. In both soils, the $\mathrm{pH}$ was alkaline. It was higher in the irrigated with clean water and at the lower profiles. The difference was found in the $0-5 \mathrm{~cm}$, and $10-40 \mathrm{~cm}$ depths. In the last one, the soil watered with clean water had a $\mathrm{pH}$ of 7.85 , and the one with sewage water, only 7.44. The electrical conductivity (EC) increased with the depth in both soils. But it was higher in the one watered with sewage water. It means that the contamination of the soil augmented the content of solutes.

Table 1: Soil analysis for the two plots, one irrigated with sewage water and the other with clean one.

\begin{tabular}{|c|c|c|c|c|c|c|c|}
\hline \multirow{2}{*}{ Soil Sample } & pH & EC & $\mathbf{O M}$ & TN & $\mathrm{NO}_{3}$ & $\mathbf{P}$ & CEC \\
\hline & 1:02 & dm sec $\sec ^{-1}$ & $\%$ & $\%$ & $\mathrm{mg} \mathrm{kg}^{-1}$ & $\mathrm{mg} \mathrm{kg}^{-1}$ & $\mathrm{C} \mathrm{mol} \mathrm{(+)} \mathrm{\textrm {kg } ^ { - 1 }}$ \\
\hline Residual Water & - & - & - & - & - & - & - \\
\hline Soil Depth $0-5 \mathrm{~cm}$ & 7.44 & 349 & 2.5 & 0.098 & 18 & 15 & 19 \\
\hline Residual Water & - & - & - & - & - & - & - \\
\hline Soil Depth 5-10cm & 7.37 & 454 & 2.48 & 0.096 & 17 & 14 & 18 \\
\hline Residual Water & - & - & - & - & - & - & - \\
\hline Soil Depth $10-40 \mathrm{~cm}$ & 7.44 & 475 & 2.45 & 0.094 & 15 & 11 & 15 \\
\hline Clean Water & - & - & - & - & - & - & - \\
\hline Soil Depth 0-5cm & 7.52 & 314 & 2.49 & 0.097 & 17 & 14 & 18 \\
\hline Clean Water & - & - & - & - & - & - & - \\
\hline Soil Depth 5-10cm & 7.75 & 332 & 2.47 & 0.095 & 16 & 13 & 17 \\
\hline Clean Water & - & - & - & - & - & - & - \\
\hline Soil Depth $10-40 \mathrm{~cm}$ & 7.85 & 384 & 2.43 & 0.092 & 13 & 10 & 13 \\
\hline
\end{tabular}




\begin{tabular}{|c|c|c|c|c|c|c|c|}
\hline \multirow{2}{*}{ Soil Sample } & $\mathrm{Ca}$ & Mg & $\mathbf{K}$ & $\mathrm{Na}$ & $\mathbf{F e}$ & Zn & $\mathrm{Cu}$ \\
\hline & $\mathrm{mg} \mathrm{kg}^{-1}$ & $\mathrm{mg} \mathrm{kg}^{-1}$ & $\mathrm{mg} \mathrm{kg}^{-1}$ & $\mathrm{mg} \mathrm{kg}^{-1}$ & $\mathrm{mg} \mathrm{kg}^{-1}$ & $\mathrm{mg} \mathrm{kg}^{-1}$ & $\mathrm{mg} \mathrm{kg}^{-1}$ \\
\hline Residual Water & - & - & - & - & - & - & - \\
\hline Soil Depth $0-5 \mathrm{~cm}$ & 1250 & 59 & 1180 & 400 & 5 & 3 & 0.5 \\
\hline Residual Water & - & - & - & - & - & - & - \\
\hline Soil Depth 5-10cm & 1210 & 56 & 1220 & 640 & 5 & 3 & 0.5 \\
\hline Residual Water & - & - & - & - & - & - & - \\
\hline Soil Depth $10-40 \mathrm{~cm}$ & 1245 & 59 & 1400 & 800 & 4 & 3 & 0.4 \\
\hline Clean Water & - & - & - & - & - & - & - \\
\hline Soil Depth $0-5 \mathrm{~cm}$ & 1240 & 58 & 1120 & 360 & 5 & 3 & 0.5 \\
\hline Clean Water & - & - & - & - & - & - & - \\
\hline Soil Depth 5-10cm & 1243 & 60 & 1110 & 640 & 3 & 3 & 0.4 \\
\hline Clean Water & - & - & - & - & - & - & - \\
\hline Soil Depth $10-40 \mathrm{~cm}$ & 1200 & 53 & 1140 & 720 & 4 & 2 & 0.4 \\
\hline
\end{tabular}

Key: $\mathrm{pH}=$ Hydrogen potential, $\mathrm{EC}=$ Electrical conductivity, $\mathrm{OM}=$ Organic matter, $\mathrm{TN}=$ Total nitrogen, $\mathrm{NO}_{3}=$ Nitric nitrogen, $\mathrm{CEC}=\mathrm{Cation}$ Exchange Capacity.

Organic matter $(\mathrm{OM})$, total nitrogen $(\mathrm{TN})$, nitric nitrogen $\left(\mathrm{NO}_{3}\right)$, phosphorous (P), Cation Exchange Capacity (CEC), calcium (Ca), potassium $(\mathrm{K})$, sodium $(\mathrm{Na})$, iron $(\mathrm{Fe})$, zinc $(\mathrm{Zn})$, and copper $(\mathrm{Cu})$ quantities were higher in the soils that were irrigated with sewage water. OM and CEC decreased with the depth.

Although, sewage water increased slightly the quantity of $\mathrm{Cu}$ as contaminants [10]. No $\mathrm{Cr}$ or Ni traces were found. The soil texture was sandy loam. Its higher infiltration rate could reduce the contaminant buildup.

The treatments affected significantly most of the variables measured. Only the fruit length and the fruit fresh weight were not influenced (Table 2). and $\mathrm{Zn}$, its levels were below the threshold for considering them

Table 2: Effect of the treatments on okra plants (Abelmoschus esculentus $(L)$ Moench).

\begin{tabular}{|c|c|c|c|c|c|c|c|}
\hline Source of variation & DF & X1 & X2 & X3 & X4 & X5 & X6 \\
\hline Treatments & 15 & 139.1208 & $1.7778^{*}$ & $79.1056^{*}$ & $34.6167^{*}$ & 18.5422 & $1021.0764^{*}$ \\
\hline Organic matter & 3 & $327.2431^{*}$ & $4.3889^{*}$ & $168.0278^{*}$ & $92.9167^{*}$ & 23.9311 & $2928.6875^{*}$ \\
\hline Soil & 1 & 54.1875 & 0.3333 & 52.0833 & $36.7500^{*}$ & 4.32 & 111.0208 \\
\hline Organic matter x Soil & 3 & 92.7986 & 0.3889 & 33.5833 & 5.3611 & 13.5756 & 316.2986 \\
\hline Strain & 1 & 180.1875 & $10.0833^{*}$ & $420.0833^{*}$ & $120.3333^{*}$ & $119.0007^{*}$ & $3870.0208^{*}$ \\
\hline Organic matter x Strain & 3 & 47.3542 & 0.0278 & 24.4722 & 4.7222 & 7.8589 & 92.2986 \\
\hline Soil x Strain & 1 & 88.0208 & 0.0833 & 30.0833 & $40.3333^{*}$ & 0.27 & 426.0208 \\
\hline Organic matter x Soil x Strain & 3 & 120.7431 & 0.5833 & 2.0278 & 4.2778 & 6.1256 & 299.0764 \\
\hline Error & 32 & 3224 & 0.5 & 27.8958 & 5.2708 & 10.8992 & 274.6042 \\
\hline Coefficient of variation & & 2.3768 & 1.4463 & 1.6129 & 1.7879 & 2.3787 & 2.612 \\
\hline
\end{tabular}

$\mathrm{X} 1=$ plant area $(\mathrm{cm}), \mathrm{X} 2=$ stem diameter $(\mathrm{mm}), \mathrm{X} 3=$ number of leaves, $\mathrm{X} 4=$ root length $(\mathrm{cm}), \mathrm{X} 5=$ root volume $(\mathrm{cm} 3), \mathrm{X} 6=$ leaf area.

*Numbers succeeded by an asterisk are significant $(p<0.05)$.

\begin{tabular}{|c|c|c|c|c|c|c|c|}
\hline Source of Variation & DF & X7 & X8 & X9 & X10 & X11 & X12 \\
\hline Treatments & 15 & 12.0389 & $3.3134^{*}$ & $5.5764^{*}$ & 28.8542 & 6.8555 & 2.164 \\
\hline Organic Matter & 3 & 19.8056 & $6.7224^{*}$ & $11.5764^{*}$ & 55.7292 & 12.4861 & $4.8041^{*}$ \\
\hline Soil & 1 & 12 & 3.4669 & $9.1875^{*}$ & 3 & 3.0502 & 3.0502 \\
\hline Organic Matter x Soil & 3 & 14.8333 & 2.7974 & 0.9653 & 0.2361 & 5.6358 & 1.3441 \\
\hline Strain & 1 & 27 & $15.0752^{*}$ & $20.0208^{*}$ & 27 & 12.9584 & 5.0052 \\
\hline Organic Matter x Strain & 3 & 5.3889 & 0.1958 & 4.2431 & 75.0139 & 6.436 & 1.5191 \\
\hline Soil x Strain & 1 & 14.0833 & 1.3002 & 2.5208 & 3.5208 & 5.4002 & 0.1519 \\
\hline Organic Matter x Soil x Strain & 3 & 2.4722 & 0.2374 & 0.5208 & 2.1181 & 2.5835 & 0.4169 \\
\hline Error & 32 & 7.5833 & 1.2923 & 2.1042 & 33.6458 & 8.26 & 1.45 \\
\hline Coefficient of Variation & & 2.1979 & 2.9172 & 2.2605 & 12.7223 & 3.6042 & 2.5713 \\
\hline
\end{tabular}

$X 7=$ foliage fresh weight $(g), X 8=$ foliage dry weight $(g), X 9=$ number of fruits, $X 10=$ fruit length, $X 11=$ fruit fresh weight, $X 12=$ fruit dry weight $(g)$. *Numbers succeeded by an asterisk are significant $(p<0.05)$. 
Vermicompost, as source of organic matter, had a positive effect on okra plants (Abelmoschus esculentus (L) Moench) growth and yield. This is consistent with the behavior found by [9] in an experiment conducted at the Postgraduate College, with Leucaena leucocephala in which the inoculated plants showed a positive effect in increasing organic matter. Dominguez et al., (2010) mentioned among the mechanisms through which this stimulation occurs include the contribution of nutrients, the improvement of the physical properties of the substrate and the contribution of microorganisms beneficial for plant development capable of increasing the availability of nutrients and produce substances with phytohormonal effects.

The contamination of the soil with sewage water and the inoculation with the Avm of Pseudomonas fluorescens had effect only on some of the variables related with the growth of okra plants (Table 2).

The lower amount of vermicompost applied (18.5g or $25 \mathrm{t}$ ha $^{-1}$ ) promoted better shoot growth (Figure 1), higher leaf area (Figure 2), and an augmented dry weight of the fruits (Figure 3). It is possible to state that the vegetative growth was improved, and the leaves were larger due to an improvement in the availability of nutrients [8]. As a result, the yield was better.

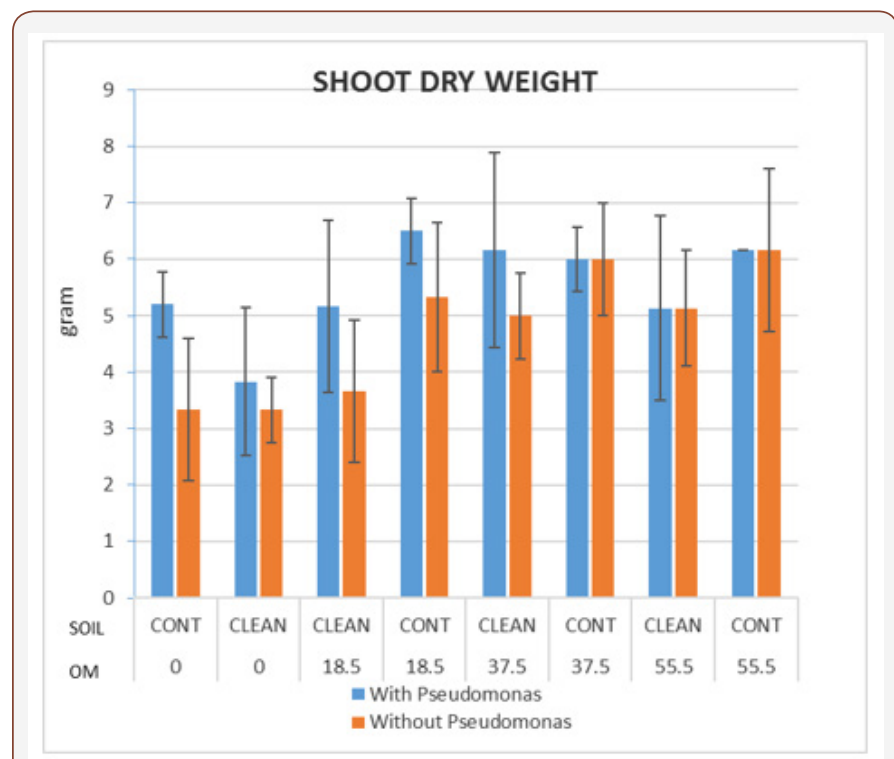

Figure 1: Effect of the inoculation with the Avm of Pseudomonas fluorescens, irrigation with two sources of water and application of organic matter on the shoot dry weight okra plants (Abelmoschus esculentus (L) Moench).

Higher quantities of organic matter (50 and $\left.75 \mathrm{t} \mathrm{ha}^{-1}\right)$ did not increase vegetative structures (Figures 1 \& 2), nor yield of okra (Figure 3). It seems that the lower amount of organic matter was able to provide the nutrients needed by the plant for optimum growth and yield.

The Avm of Pseudomonas fluorescens was better promoting vegetative growth, measured as plant height, stem diameter or shoot dry weight, especially in plants without organic matter added or with the lowest amount [11-13]. The gave better results in soils contaminated with sewage water (Figure 1). A less pronounce patter was found in leaf number and leaf area (Figure 2).

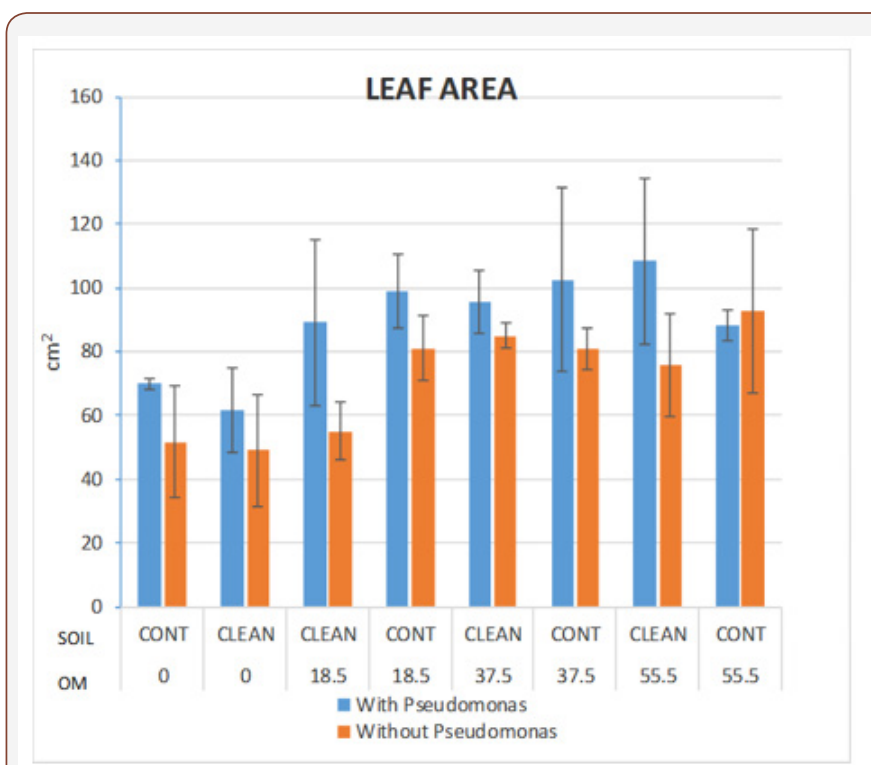

Figure 2: Effect of the inoculation with the Avm of Pseudomonas fluorescens, irrigation with two sources of water and application of organic matter on the leaf area of okra plants (Abelmoschus esculentus (L) Moench).

Fluorescent pseudomonads inoculated in okra gave higher yields with the application of organic matter. The higher amount of vermicompost in soil contaminated with sewage water was the exception (Figure 3).

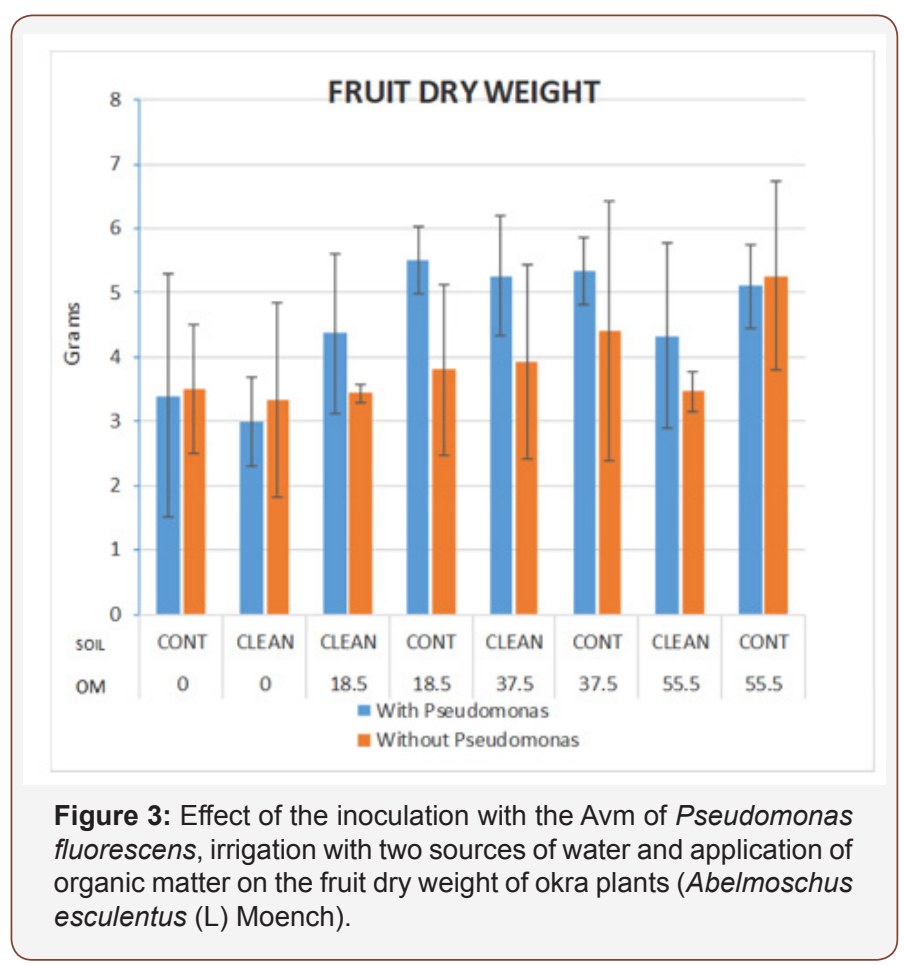

A similar pattern was found in the roots. Root length, and root volume augmented with the application of lower quantities of organic matter (25t ha-1) and the inoculation with the Avm of Pseudomonas fluorescens in soils contaminated with sewage water. 
The lower amount of vermicompost applied (18.5g or 25t ha $\left.{ }^{1}\right)$ inoculated with the Avm of Pseudomonas fluorescens in soils contaminated with sewage water was the best combination to promote better shoot growth (Figure 1), higher leaf area (Figure 2), and an augmented dry weight of the fruits (Figure 3).

\section{Conclusion}

The use of Pseudomonas fluorescens can help to overcome the negative effects of contaminated waters, and other environmental and biological stresses. Recommendations are made to validate this result under field conditions.

\section{Acknowledgement}

None.

\section{Conflict of Interest}

No conflict of interest.

\section{References}

1. Bulluck LR, JB Ristaino (2002) Effect of synthetic and organic soil fertility amendments on southern blight, soil microbial communities, and yield of processing tomatoes. Phyopath 92(2): 181-189.

2. Garbeva P, J Postma, JA Van Veen, JD Van Elsas (2006) Effect of aboveground plant species on soil microbial community structure and its impact on suppression Rhizoctonia salami AG3. Environ Microbiol 8(2): 233-246.

3. Larkin RP, CW Honeycutt (2006) Effect of different 3-year cropping systems on soil microbial communities and rhizoctonia diseases of potato. Phytopathology 96(1): 68-79.

4. Afzal S, S Tariq, V Sultana, J Ara, S Ehteshamul Haque (2013) Managing the root diseases of okra with endo-root plant growth promoting Pseudomonas and Trichoderma viride associated with healthy okra roots. Pak J Bot 45(4): 1455-1460.
5. Shafique HA, R Noreen, V Sultana, J Ara, S Ehteshamul Haque (2015) Effect of endophytic Pseudomonas aeruginosa and Trichoderma harzianum on soil-borne diseases, mycorrhizae and induction of systemic resistance in okra grown in soil amended with Vernonia anthelmintica (L) seed's powder. Pak J Bot 47(6): 2421-2426.

6. Gao G, Yin D, Chen S, Xia F, Yang J, et al. (2012) Effect of biocontrol agent Pseudomonas fluorescens 2P24 on soil fungal community in cucumber rhizosphere using T-RFLP and DGGE. PlosOne 7(2): e31806.

7. Mputu KJN, Pierart C, Destain J, Noki P, Thonart P (2014) Impact du séchage sur la viabilité de Pseudomonas flourescens (synthèse bibliographique). 18(1): 134-141.

8. Gardezi AK, Márquez Berber SR, Figueroa Sandoval B, Almaguer Vargas A, Larqué Saavedra U, et al. (2014) Organic matter effect on glomus intrarradices in beans (phaseolus vulgaris l) Growth cultivated in soils with two sources of water under greenhouse conditions. systemics, cybernetics and informatics 12(1): 63-68.

9. Gardezi AK, Marquez Berber SR, Mario Martinez Menes, Hector Flores M, Escalona Maurice MJ, et al. (2017) Soil contamination and its effects on roselle (Hibiscus Sobdarifa) growth affected by organic matter and associated with Glumus intrarradices. procceding of $10^{\text {th }}$ International conference on Agriculture and Horticulture, london, UK 6(4).

10. Uvalle Bueno JX, Aguilar Santelisis A (2000) Manual de interpretación de análisis de suelos y aguas. Second. Mexico: Instituto de Capacitación para la Productividad Agrícola.

11. Adesemoye AO, M Obini, EO Ugoji (2008) Comparison of plant growthpromotion with Pseudomonas aeruginosa and Bacillus subtilis in three vegetables. Brazilian Journal of Microbiology 39(3): 423-426.

12. Darake MS (2015) Effect of inoculation of VAM fungi on enhancement of biomass and yield in Okra. IJSET 2(8): 859-865.

13. Senthilkumar T, Ramakrishnan S (2004) Studies on Compatibility of Pseudomonas fluorescens, Trichoderma viride and Carbofuran 3G and Their Influences on Meloidogyne incognita in Okra. Annals of Plant Protection Sciences 12(1): 140-142. 